\title{
Overview of the D.O.E. Energy Storage R\&D: Status for FY 2006
}

\author{
Tien Q. Duong*, David Howell*, James Barnes*, \\ Gary Henriksen**, and Venkat Srinivasan ${ }^{\circ}$
}

This paper presents an overview, including highlights and accomplishments, of the energy storage R\&D effort at the FreedomCAR and Vehicle Technologies Program Office of the United States Department of Energy (DOE) during the Fiscal Year 2006 (and the early part of FY 2007). DOE maintains a close partnership with the automotive industry through the United States Advanced Battery Consortium (USABC) to support the development of advanced energy storage technologies, including batteries and ultracapacitors, for transportation applications. It leverages resources and expertise from automobile manufacturers, battery developers, small businesses, national laboratories, and universities to address the technical barriers which prevent the market introduction of vehicles using advanced energy storage technologies. The energy storage research activities include the developer program, applied battery research, and long-term focused fundamental research; which are organized to complement each other. The developer program is conducted in collaboration with battery developers and original equipment manufacturers (OEMs) and includes benchmark testing, technology assessments, and system development. Applied battery research is focused on addressing cross-cutting barriers for high-power lithium-ion systems, which include the barriers of insufficient life, inadequate low temperature performance, inability to tolerate abuse, and a high cell-level cost. Focused fundamental research addresses critical problems of chemical instabilities for advanced batteries and attempts to better understand why systems fail, develops models to predict system failure and to enable optimization, and researches promising new materials. The paper also describes DOE's current energy storage R\&D coordination efforts with other agencies.

Keywords: Battery, On-Board Energy Storage System, Li-Ion Battery, Electrolyte, Electrodes

\section{INTRODUCTION}

Energy storage technologies, especially batteries, represent a critical enabling technology for the successful commercialization of a wide range of advanced, fuelefficient, light- and heavy-duty vehicles, including hybrid electric vehicles (HEVs) and fuel cell vehicles (FCVs). Advanced batteries can also be the primary power source for plug-in hybrid electric vehicles (PHEVs) and battery electric vehicles (EVs). The FreedomCAR and Vehicle Technologies (FCVT) Program at the United States Department of Energy (DOE) supports R\&D on advanced batteries and ultracapacitors. It plans to help develop affordable and advanced batteries for a full range of automotive applications. The 2010 goal of the FCVT Program is to develop electric drive-train energy storage with a discharge power of $25 \mathrm{~kW}$ for 10 seconds, which can provide $300 \mathrm{Wh}$ of available energy, has a 15-year life, and whose cost does not exceed

\footnotetext{
* U.S. Department of Energy

** Argonne National Laboratory

○ Lawrence Berkeley National Laboratory

(C) 2008 WEV Journal
}

$\$ 20 / \mathrm{kW}$ [1]. This goal would ensure that the resulting HEVs can favorably compete with conventional vehicles on a cost and performance basis. The DOE maintains a close partnership with the automotive industry through the United States Advanced Battery Consortium (USABC) to support the development of such technologies. It leverages all available resources, including those of automobile manufacturers, battery developers, small businesses, national laboratories, and universities to address the technical barriers preventing the introduction of battery systems to the marketplace. In 1997, recognizing that most candidate battery systems suffered from similar problems of abuse tolerance, calendar life and cost; it initiated the applied battery research activity based at the national laboratories. In 2000, a long-term exploratory research activity entitled Batteries for Advanced Transportation Technologies (BATT) was set up to focus on the fundamental impediments to the development of such batteries. Table 1 shows the fiscal year (FY) 2001-2008 FCVT budgets for energy storage R\&D. For FY 2008, the President's budget requests approximately $\$ 41.8$ million for this effort. Industrial partners funded by the USABC must share at least 50 percent of the cost of 


\begin{tabular}{|l|r|r|r|r|r|r|r|r|}
\hline Fiscal Year & 2001 & 2002 & 2003 & 2004 & 2005 & 2006 & 2007 & $2008 *$ \\
\hline Budget $(\$$, Million) & $\$ 26.3$ & $\$ 24.8$ & $\$ 21.2$ & $\$ 22.3$ & $\$ 22.5$ & $\$ 24.5$ & $\$ 40.9$ & $\$ 41.8$ \\
\hline
\end{tabular}

Table 1: Recent energy storage R\&D budgets

* President's request

each development effort. This research effort has been highlighted in several prior EVS overview papers [e.g., $2-4]$.

\section{TECHNICAL BARRIERS, TARGETS, AND CURRENT STATUS}

To accomplish the FCVT energy storage goals, it is necessary to set energy storage performance targets and address the technical barriers which prevent reaching those targets. Over time, it is also necessary to take stock of the status of the technologies, in order to track the progress in overcoming the barriers.

\subsection{Technical Barriers and Targets}

Overall, the technical barriers to the successful commercialization of advanced energy storage technologies for transportation are associated with cost, performance, life, and abuse tolerance. Of these, cost is the overriding factor. The other factors also indirectly impact the battery cost. All batteries face challenges associated with battery life. Often, the battery life is uncertain due to its dependence on many internal battery parameters and external factors. Finally, it is critical for any new vehicle technology to operate safely under both routine and extreme conditions - including conditions of high temperature, overcharge, and short circuit.

Technical targets for individual battery applications have been developed in collaboration with the USABC on the basis of input from the purchasers and end-users of these technologies. A partial listing of the current targets for high voltage, power assist HEVs appears in Table 2. Additional performance targets (e.g., for EVs, ultracapacitors, and PHEVs) appear at the USABC website [5] and are also reported in the FCVT Energy Storage R\&D annual progress report [6]. More recently, a significant focus of the energy storage R\&D is the development of batteries for PHEV applications.

\subsection{Current Status}

For power-assist HEV applications, as described in a previous EVS overview paper [2], the FreedomCAR goals for key parameters like available energy, pulse power, cycle life, system weight, and system volume have all been met or exceeded by existing technologies. Among the remaining parameters, the selling price needs to be reduced by approximately a factor of two or three to reach the goals. Goals also need to be met or demonstrated for the operating temperature and calendar life.

For PHEV batteries, the cost and the performance at low temperatures appear to be major barriers. Also, the impact of deep and shallow cycles on the overall life remains to be understood. Figure 1 tracks the current progress toward commercial viability for various energy storage technologies for both HEV and PHEV applications. It is observed that the advanced energy storage technologies for HEV applications are further along than those for PHEV applications. The R\&D technologies supported by DOE span several development phases, including those of material development (as seen in the case of the Li Metal/Li-ion polymer system), cell development (for the graphite/

\begin{tabular}{|c|c|c|}
\hline Characteristics & Minimum value & Maximum value \\
\hline Pulse discharge power (kW) & 25 (for 18 seconds) & 40 (for 18 seconds) \\
\hline Maximum regenerating pulse (18 $s ; k W)$ & 20 (50 Wh pulse) & 35 (97 Wh pulse) \\
\hline Total available energy (kWh) & 0.3 & 0.5 \\
\hline Round trip efficiency $(\%)$ & $>90-25$ Wh cycle & $>90-50 \mathrm{Wh}$ cycle \\
\hline $\begin{array}{l}\text { Cycle life for specified SOC increments } \\
\text { (cycles) }\end{array}$ & $\begin{array}{l}\text { 300k 25-Wh cycle } \\
\text { (7.5 MWh) }\end{array}$ & $\begin{array}{l}\text { 300k } 50-\text { Wh cycle } \\
\text { (15 MWh) }\end{array}$ \\
\hline Calendar life (years) & 15 & 15 \\
\hline Maximum weight (kg) & 40 & 60 \\
\hline Maximum volume (liters) & 32 & 45 \\
\hline
\end{tabular}

Table 2: FreedomCAR energy storage performance targets for high voltage, power-assist HEVs (Partial data, from the FCVT Energy Storage R\&D annual progress report [6]) 
Mn spinel system), battery development (for the graphite/iron phosphate system), and cost-reduction (for ultracapacitors and low-cost separators).

\section{ENERGY STORAGE R\&D ACTIVITIES}

The energy storage effort includes multiple activities - from hardware development with industry, to midterm R\&D and long-term research. The activities begin establishing technical requirements for the energy storage technologies by FCVT in cooperation with industry. Next, commercially available batteries are evaluated against those requirements. If still unmet, additional R\&D is undertaken, involving either short-term directed research (applied research) by commercial developers and the national laboratories, or more long-term exploratory research, generally by national laboratories and universities. The three energy storage R\&D activities; the developer program, applied battery research, and focused fundamental research, are organized to complement each other.

\subsection{The Developer Program}

\subsubsection{BACKGROUND}

The developer program's goal is to support the development of a U.S. domestic advanced battery industry whose batteries meet the USABC technical goals. DOE works closely with industry to develop

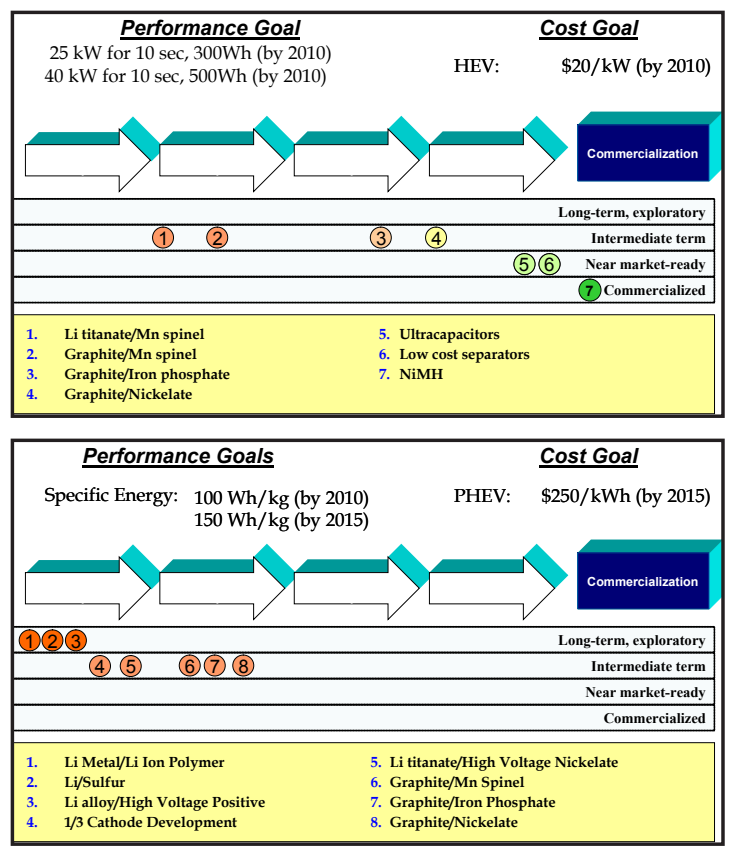

Figure 1: Status of energy storage R\&D technologies for (a) HEV applications, and for (b) PHEV applications energy storage technologies for specific applications. The developer program includes system development, technology assessments and benchmark testing, as described below.

\subsubsection{DEVELOPER PROGRAM ACTIVITIES}

DOE works with industry through cost-shared projects to develop electrochemical energy storage technologies which would meet FreedomCAR/USABC technical goals. The USABC provides technical and programmatic management of these projects, whose cost is shared by the individual developer at a minimum level of 50 percent. The technologies include lithium-ion batteries and ultracapacitors. They also include separators, since separators contribute significantly to the total system cost. Some of the current development activities are listed in Table 3. More information on each project is available in the FCVT Energy Storage R\&D annual progress report [6].

Reducing the cost of the end product is the primary objective of each project. The Johnson Controls Saft (JCS) lithium-ion $40 \mathrm{~kW}$ power assist hybrid contract is focusing on low cost manufacturing. The Compact Power, Inc. (CPI)/LG Chem $25 \mathrm{~kW}$ power assist system lithium-ion system uses low-cost spinel cathode with a gel-polymer electrolyte, and a laminated cell design. EnerDel is developing very high rate and potentially low-cost materials for lithium-ion batteries for the $25 \mathrm{~kW}$ power-assist systems. The list also includes projects on low-cost separators by Celgard and Ultimate Membrane Technologies (UMT); and on ultracapacitors by Maxwell, and NESSCAP. Additional R\&D involves the thermal management of battery systems, since poor thermal management can lead to degradation in battery performance and a substantial increase in cost, a reduced cycle/calendar life, and an increased chance of encountering abusive conditions. It includes the thermal analysis and characterization of cells and modules through simulation and testing.

Technology assessments are conducted on newly emerging technologies before developing full systems. The assessments typically represent 12-month projects to assess a developer's overall capabilities and are intended to validate the developer's technical claims. Benchmark testing of emerging technologies is important for remaining abreast of the latest industry developments. Representative battery technologies are evaluated according to either the USABC Battery Test Procedures Manual (for EV batteries) [7] or the Partnership for a New Generation of vehicles (PNGV) Battery Test Procedures Manual (for HEV batteries) [8]. Additional developer support comes from the small business innovation research (SBIR) program. Over 
the past years, SBIR contracts have provided valuable support to EV and HEV battery development efforts. Currently active Phase I and Phase II energy storage SBIR contracts represent a value of over $\$ 8$ million being spent at the rate of $\$ 2-\$ 3$ million per year. The SBIR projects are focused on the development of new battery materials and components. A list of the current SBIR contracts appears in the FCVT Energy Storage R\&D annual progress report [6].

Some of the numerous recent accomplishments of the developer program include the following:

- Cobasys (supplier of HEV batteries to GM) developed NiMH technology with USABC support. DOE receives a portion of the royalties from the sale of all NiMH batteries which use any intellectual property associated with the earlier USABC funding of that technology.

- General Motors (GM) has contracted with A123Systems, CPI/LG Chem, and Johnson Controls/Saft to supply prototype PHEV Li-ion batteries, all have worked extensively with the USABC.

\subsection{Applied Battery Research}

The applied battery research activity - also called the Advanced Technology Development (ATD) activity, focuses on the barriers for high-power Li-ion batteries and attempts to understand the factors that limit calendar life, abuse tolerance, and performance over the desired operational temperature range. It addresses the cost barrier at the cell level through the identification and development of lower-cost and more stable cell materials and components. It seeks to advance more optimal cell chemistries through the identification and development of cell materials that are chemically, structurally, electrochemically, and thermally stable in the cell environment and also have a cost advantage over current materials. Five DOE national laboratories collaborate in this activity which is coordinated for the DOE by the Argonne National Laboratory (ANL). The other four DOE laboratories are Brookhaven National Laboratory (BNL), Idaho National Laboratory (INL), Lawrence Berkeley National Laboratory (LBNL), and Sandia National Laboratories (SNL). The individual task areas for participating laboratories are shown in Table 4.

\begin{tabular}{|c|c|c|}
\hline Technology & Developer/contractor (Duration) & Highlights \\
\hline Li-ion (40 kW, HEV) & Johnson Controls Saft (JCS) (24 months) & $\begin{array}{l}\text { o Effort is led by advanced battery system team } \\
\text { at Milwaukee, WI. } \\
\text { o Effort is focusing on reducing system cost } \\
\text { through high volume production techniques, } \\
\text { and improved abuse tolerance. } \\
\text { o Initial results should electrodes that are } \\
\text { identical to those produced at Saft Bordeaux. }\end{array}$ \\
\hline $\begin{array}{l}\text { Li-ion Polymer (25 kW HEV) (Mn spine1- } \\
\text { based cathode) }\end{array}$ & Compact Power/LG Chem (18 months) & $\begin{array}{l}\text { - Will evaluate a new separator which promises } \\
\text { improved abuse tolerance. } \\
\text { o Includes evaluation of the ability of pouch } \\
\text { packaging to attain a } 15 \text {-year life. } \\
\text { o Barriers include calendar life (particularly at } \\
\text { elevated temperatures) and cost }\end{array}$ \\
\hline Li-ion ( $25 \mathrm{~kW}$ HEV) & EnerDel (12 months) & $\begin{array}{l}\text { o Will produce a nano-phase Li-titanate } \\
\text { (LiTO)/Mn spinel large-format cell. } \\
\text { o Nano-phase LiTO is characterized by } \\
\text { extremely small primary particles ( } 10 \text { to } 20 \mathrm{~nm} \text {, } \\
\text { agglomerated into } 1-2 \text { micrometer for easier } \\
\text { processing) } \\
\text { o Barriers include life and demonstration of } 10 \mathrm{w} \\
\text { cost. }\end{array}$ \\
\hline Li-ion (25kW HEV) & A123Systems (24 months) & $\begin{array}{l}\text { o Modify nano-phase iron-phosphate power } \\
\text { tool cell for } 25 \mathrm{~kW} \text { HEVs. } \\
\text { o Will manufacturer larger cells, improve the } \\
\text { specific power, demonstrate abuse tolerance. } \\
\text { o Barriers include cost and demonstration of } \\
\text { life. }\end{array}$ \\
\hline \multirow[t]{2}{*}{ Low cost separator (42V Start/Stop) } & Celgard, Inc. (56 months) & $\begin{array}{l}\text { o Focused on developing low-cost separator } \\
\text { material with high temperature melt integrity. }\end{array}$ \\
\hline & $\begin{array}{l}\text { Ultimate Membrane Technologies } \\
\text { (UMT) (48 months) }\end{array}$ & $\begin{array}{l}\text { o Focused on demonstrating the process } \\
\text { uniformity } / \text { reproducibility of } 135^{\circ} \mathrm{C} \\
\text { shutdown } 165^{\circ} \mathrm{C} \text { melt integrity material, } \\
\text { followed by further exploration. Completed in } \\
\text { August } 2006 \text {. }\end{array}$ \\
\hline \multirow[t]{2}{*}{ Ultracapacitor (42V Start/Stop) } & Maxwell (24 months) & $\begin{array}{l}\text { Completed design validation and delivery of } \\
2.85 \mathrm{~V}, 3600 \mathrm{~F} \text { cells. Completed in September } \\
2006 \text {. }\end{array}$ \\
\hline & NESSCAP (24 months) & $\begin{array}{l}\text { - It was found that a PC based electrolyte is } \\
\text { unlikely to meet the performance targets. } \\
\text { o Focused on producing a larger cell with high } \\
\text { performance electrodes using advanced carbon } \\
\text { binders. }\end{array}$ \\
\hline
\end{tabular}

Table 3: Developer program activities (summarized from the FCVT Energy Storage R\&D 2006 annual progress report [6]) 


\begin{tabular}{|c|c|c|c|c|c|}
\hline Task & ANL & BNL & INL & LBNL & SNL \\
\hline 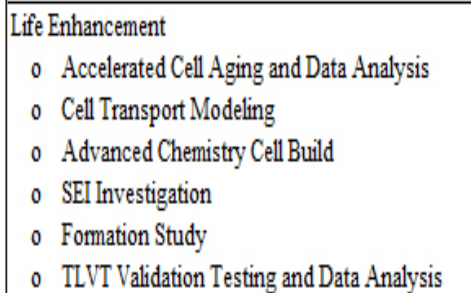 & $\begin{array}{l}X \\
X \\
X \\
X \\
X \\
X\end{array}$ & $\mathrm{X}$ & $\begin{array}{l}X \\
X\end{array}$ & $\begin{array}{l}x \\
x \\
x\end{array}$ & X \\
\hline \begin{tabular}{|c|c|} 
Low & Temperature Performance \\
0 & Characterize Gen 3 Cell Chemistry \\
0 & Reference Electrode Diagnostics \\
0 & Electrolyte Modeling \\
0 & Electrochemical Cell Modeling \\
0 & Evaluate Alternative Materials \\
\end{tabular} & $\begin{array}{l}X \\
X \\
X\end{array}$ & & $\begin{array}{l}X \\
X \\
X\end{array}$ & & \\
\hline \begin{tabular}{|l} 
Abuse Tolerance \\
o DSC and ARC on Advanced Materials \\
o ARC and Themal Block Tests on 18650 Cells \\
- Overcharge Tests with Advanced Materials \\
- Diagnostics on Abused Cell Materials and \\
Components \\
O Model 18650 Cell Behavior \\
\end{tabular} & $\begin{array}{l}X \\
X \\
X\end{array}$ & $X$ & & & $\begin{array}{l}X \\
X \\
X \\
X\end{array}$ \\
\hline 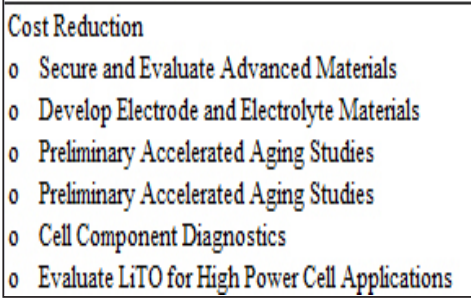 & $\begin{array}{l}X \\
X \\
X \\
X \\
X \\
X\end{array}$ & & & & \\
\hline
\end{tabular}

Table 4: Task areas for national laboratory participants in the applied battery research activity

In recent years, this activity has thoroughly studied and characterized its own cell chemistry, which has evolved from Gen 1, to Gen 2, to the current Gen 3. Their chemistries were described in earlier overview papers [2-4] and are summarized in Table 5. Cells employing the new Gen 3 chemistry, lithium-rich $\mathrm{LiNi}_{1 / 3} \mathrm{Mn}_{1 / 3} \mathrm{Co}_{1 / 3} \mathrm{O}_{2}$ (called NMC or 1/3) layered cathode material and a synthetic graphite anode (MCMB 10-28), have demonstrated increased inherent abuse tolerance and are currently undergoing accelerated life testing. More recently, this activity has expanded investigation into the fundamental limitations associated with low temperature performance, into the characteristics of the solid electrolyte interphase (SEI) and into how those are impacted by formation conditions. In particular, a new capability to create binder and carbon free electrodes has enabled detailed in-situ diagnostics of the new Gen 3 cathode material with formation approaches. Table 6 provides a list of recent highlights and accomplishments for the different focus areas of the Applied Battery Research activity for FY 2006. Additional details are available in the FCVT Energy
Storage R\&D annual progress report [6].

\subsection{Long-term Focused Fundamental Research}

The long-term focused fundamental research activity, also called the Batteries for Advanced Transportation Technologies (BATT) activity, addresses the fundamental issues of chemistries and materials associated with lithium batteries. It emphasizes the identification and mitigation of failure modes, coupled with materials synthesis and evaluation, advanced diagnostics, and improved electrochemical models. Battery chemistries are monitored continuously with periodic substitution of more-promising components based on advice from within this activity, from outside experts, and from assessments of world-wide battery R\&D. The work is carried out by a team headed by the Lawrence Berkeley National Laboratory (LBNL) and involves ANL, BNL, and several universities (Univs of Texas, Utah, Michigan, MIT, Clemson, Brigham Young, SUNY, and Columbia). It has carried out investigations into three baseline systems: 


\begin{tabular}{|c|c|c|c|}
\hline & Component & Material & $\begin{array}{c}\text { Percent } \\
(\%)\end{array}$ \\
\hline \multirow[t]{8}{*}{ Gen1 } & \multirow[t]{4}{*}{ Cathode } & $\mathrm{LiNi}_{0.8} \mathrm{C}_{0.2 .2} \mathrm{O}_{2}$ & $84 \%$ \\
\hline & & Acetylene black & $4 \%$ \\
\hline & & SFG-6 graphite & $4 \%$ \\
\hline & & PVDF binder & $8 \%$ \\
\hline & \multirow[t]{3}{*}{ Anode } & MCMB-6-2800 graphite & $75 \%$ \\
\hline & & SFG-6 graphite & $16 \%$ \\
\hline & & PVDF binder & $9 \%$ \\
\hline & Electrolyte & 1.0 M LiPF6 in EC:DEC (1:1) & - \\
\hline \multirow[t]{7}{*}{ Gen2 } & \multirow[t]{4}{*}{ Cathode } & $\begin{array}{l}\mathrm{LiNi}_{0.8} \mathrm{Co}_{0.15} \mathrm{Al}_{0.05} \mathrm{O}_{2} \text { (Baseline), or } \\
\mathrm{LiNi}_{0.8} \mathrm{Co}_{0.10} \mathrm{Al}_{0.10} \mathrm{O}_{2} \text { (Variant } \mathrm{C} \text { ), or } \\
\mathrm{LiNi}_{0.8} \mathrm{Co}_{0.15} \mathrm{Al}_{0.05} \mathrm{O}_{2} \text { (GDR) }\end{array}$ & $84 \%$ \\
\hline & & \begin{tabular}{|l} 
SFG-6 graphite \\
\end{tabular} & $4 \%$ \\
\hline & & Carbon black & $4 \%$ \\
\hline & & PVDF binder & $8 \%$ \\
\hline & \multirow[t]{2}{*}{ Anode } & $\begin{array}{l}\text { Mag-10 graphite (Baseline, Variant C), or } \\
\text { GDR graphite (GDR) }\end{array}$ & $92 \%$ \\
\hline & & PVDF binder & $8 \%$ \\
\hline & Electrolyte & 1.2 $\mathrm{MLiPF}_{6}$ in EC:EMC (3:7) & - \\
\hline \multirow[t]{7}{*}{ Gen3 } & \multirow[t]{3}{*}{ Cathode } & $\mathrm{Li}_{1.05}\left(\mathrm{Ni}_{1 / 3} \mathrm{Co}_{1 / 3} \mathrm{Al}_{1 / 3}\right)_{0.95} \mathrm{O}_{2}$ & $84 \%$ \\
\hline & & Carbon black & $8 \%$ \\
\hline & & PVDF binder & $8 \%$ \\
\hline & \multirow[t]{3}{*}{ Anode } & MCMB 10-28 & $90 \%$ \\
\hline & & Graphite fiber & $2 \%$ \\
\hline & & PVDF binder & $8 \%$ \\
\hline & Electrolyte & 1.2 $\mathrm{MLiPF}_{6}$ in $\mathrm{EC}: \mathrm{EMC}(3: 7)$ & - \\
\hline All & Separator & $25 \mu \mathrm{m}$ polyethylene & - \\
\hline
\end{tabular}

Table 5: The evolution of the cell chemistries for the applied battery research activity

- The $\mathrm{LiNi}_{1 / 3} \mathrm{Mn}_{1 / 3} \mathrm{Co}_{1 / 3} \mathrm{O}_{2}$ cathode material in a high-energy cell with a $\mathrm{LiPF}_{6}$-EC-DEC electrolyte and a carbon-coated graphite anode. This cathode is less expensive than the Gen 2 cathode.

- A low cost and abuse tolerant $\mathrm{LiFePO}_{4}$ system to develop significantly improved materials using liquid or gel electrolytes. This is regarded as a moderate-energy, low-voltage system that is inherently stable and low cost.

-Ahigh-rate spinel system with a liquid-electrolyte, aiding work in the applied battery research to develop a low-cost high-power battery.
This work focuses on some of the most promising chemistries in the Li-ion battery field while also collaboratively addressing the barriers common to all of them. In the past, it was conducted through six specific research tasks as described in a prior EVS overview paper [2]. Based on feedback obtained during a recent planning meeting, this activity was recently restructured to accommodate the concept of themebased research in addition to exploratory research. In the new structure, some members of the BATT activity are arranged around broad themes, while others continue the synthesis and characterization of new 
anodes, cathodes, and electrolytes for use in the nextgeneration Li-ion chemistries. The currently identified themes are:

- Improving the energy and life of PHEV batteries,

- Studying the impact of nanomaterials on battery behavior, with emphasis on phosphate cathodes and alloys and intermetallic anodes, and

- Understanding interfacial processes with emphasis on characterization of the solid electrolyte interphase (SEI) and on reactions in composite cathodes at potential greater than 4.3 $\mathrm{V}$.

\begin{tabular}{|c|c|}
\hline Focus Area & Highlights \\
\hline $\begin{array}{l}\text { Understand life-limiting mechanisms and } \\
\text { enhance life }\end{array}$ & $\begin{array}{l}\text { Developed carbon \& binder free Gen } 3 \text { type cathodes and binder } \\
\text { free graphite anodes for use in SEI studies. } \\
\text { o Examined the effect of temperature and upper cutoff voltage in the } \\
\text { formation process on cell performance and determined that cells } \\
\text { formed at } 0 \text { oC have relatively higher ASI, higher interfacial } \\
\text { impedance, and lower capacity than those at higher temperature. } \\
\text { o Studied electrodes from cells subjected to various formation cycle } \\
\text { protocols and determined that the major differences are as sociated } \\
\text { with films on the negative electrode. } \\
\text { o Determined that the negative electrode graphite particles from } \\
\text { higher impedance cells have a thicker, denser, and more LiF-rich SEI } \\
\text { layer. } \\
\text { o Demonstrated that the use of an electrolyte additive to produce a } \\
\text { more stable SEI on the negative electrode is key to achieving elevated } \\
\text { temperature stability with Gen } 3 \text { cell chemistry. }\end{array}$ \\
\hline $\begin{array}{l}\text { Understand and enhance low-temperature } \\
\text { performance }\end{array}$ & $\begin{array}{l}\text { Determined that, in general, changes in active material and } \\
\text { electrolyte do not significantly impact the poor low-temperature } \\
\text { performance. } \\
\text { o Results from binder and carbon free electrodes showed that the } \\
\text { impedance rise at low temperature is due to interfacial effects on the } \\
\text { active material particles. } \\
\text { o Found that high surface area particles improve the low- } \\
\text { temperature performance but provide only part of the solution. } \\
\text { o Found that the addition of methyl butyrate significantly reduced } \\
\text { viscosity and increases wet-ability to separator. }\end{array}$ \\
\hline $\begin{array}{l}\text { Understand and enhance inherent abuse } \\
\text { tolerance }\end{array}$ & $\begin{array}{l}\text { Determined that heat observed below } 180^{\circ} \mathrm{C} \text { due to continuous } \\
\text { breakdown and formation of the anode } \mathrm{SEI} \text { may initiate thermal } \\
\text { runaway of the cell. This heat could be reduced through use of low } \\
\text { surface area round edge carbon, and additives that form a more stable } \\
\mathrm{SEI} \text {. } \\
\text { o } \mathrm{Li}_{4} \mathrm{Ti}_{5} \mathrm{O}_{12} \text { anode showed very little heat generation up to } 375^{\circ} \mathrm{C} \text {. } \\
\text { o The oxidation of the electrolyte due to } \mathrm{O}_{2} \text { release from the cathode } \\
\text { was found to be the main cause of thermal runaway in many } \\
\text { cathodes. } \\
\text { o Spinel and olivine cathodes showed by far the best thermal abuse } \\
\text { response. } \\
\text { o It was found that (a) electrolyte additives can reduce reactivity } \\
\text { and gas phase flammability, (b) separator breakdown can result after } \\
\text { shutdown, (c) non-shutdown separators may give enhanced abuse } \\
\text { tolerance for cell strings and modules, and (d) anode reactivity is of } \\
\text { equal magnitude compared to new stabilized NMC } \\
\text { (Lili.1(Ni } \mathrm{Ni}_{1 / 3} \mathrm{Co} / 3 \mathrm{Mn} \mathrm{N}_{1 / 3} \text { ) } 9 \mathrm{O}_{2} \text { ] cathodes. } \\
\text { o The } \mathrm{NMC} \text { cathode showed improved overcharge tolerance versus } \\
\mathrm{NCA} \text { cathodes. }\end{array}$ \\
\hline $\begin{array}{l}\text { Lower cell-level costs via lower cost } \\
\text { materials, components, and technologies }\end{array}$ & $\begin{array}{l}\text { - Obtained samples of advanced natural and synthetic graphite } \\
\text { materials, lithium titanates, advanced layered and } 3 D \text { spinel cathode } \\
\text { materials, and electrolyte salts for evaluation and screening. } \\
\text { o Conducted screening tests on advanced materials. } \\
\text { o Established that the nano composite LiTO cells performed as well } \\
\text { as (or better than) other similar cells. } \\
\text { o Established that electrolyte additives can stabilize the } \\
\text { electrode/electrolyte interfaces to extend the calendar life of the } \\
\text { graphite/L333 cell chemistry while retaining power. }\end{array}$ \\
\hline
\end{tabular}

Table 6: Recent highlights from the applied battery research activity (summarized from the FCVT Energy Storage R\&D 2006 annual progress report [6]) 
The above themes are intended to maximize BATT impact on addressing the pressing issues related to PHEV commercialization, namely cost and cycle/ calendar life. A 40-mile range PHEV would require an approximately $15 \mathrm{kWh}$ battery, whose cost would be considerable. It is possible to decrease this cost if one could increase the energy of the cell thereby needing fewer cells. BATT will pursue two avenues to achieve this goal: first by engineering existing materials to improve their energy; and second, by developing new materials that have more energy per unit mass and volume. While the engineering approach could yield results in the short-term, the longer-term materials research is expected to lead to a much larger impact in the future. PHEV batteries may need to undergo 3,500 deep-discharge cycles over a 15 -year period. BATT will be studying two fundamental issues that limit the life of batteries under deep discharge cycle: the formation of the SEI and its stability through the life of the battery; and the processes that occur in cathodes at a potential above $4.3 \mathrm{~V}$. Table 7 summarizes the recent R\&D activities under each BATT research area - along with the participating laboratory/university. Additional information is available in the FCVT Energy Storage R\&D annual progress report [6] and at the BATT website [9]. Table 8 lists some recent highlights for the activities.

\begin{tabular}{|c|c|}
\hline Task & Research Project (participant) \\
\hline \multirow[t]{3}{*}{ New Cathode Materials } & $\begin{array}{l}\text { LiFePO and other Phosphate Systems: Performance and Limitations } \\
\text { o Hydrothermal Synthesis of } \mathrm{LiFePO}_{4} \text { : Control of Particle Size \& } \\
\text { Morphology, } \\
\text { and Phase Transition Study (LBNL) } \\
\text { o Microwave Assisted Plasma (MPA) Carbon Deposition (LBNL) } \\
\text { o Carbon Films and Their Impact on Capacity Fade (LBNL) } \\
\text { o Low-Temperature (Low-Cost) Formation of Lithium Iron Phosphate } \\
\text { (SUNY, Binghamton) } \\
\text { o Theoretical Investigation of Iron Phosphate Phase Diagram (SUNY, Stony } \\
\text { Brook) } \\
\text { o Conductive and Electroactive Polymers, Higher Energy Phosphates (UT, } \\
\text { Austin) } \\
\text { o New Conductive Carbons (BYU) } \\
\text { o In-situ and Ex-situ Investigation of Phosphates (BNL) }\end{array}$ \\
\hline & $\begin{array}{l}\text { Spinel and Composite Systems: Performance and Limitations } \\
\text { o Doped Spinels (UT, Austin) } \\
\text { o In-situ Diagnostics of Spinels (BNL) } \\
\text { o Layered and Spinel Composite Cathodes, Structural Changes (ANL) } \\
\text { o Nanoparticle Coatings and Improved Electrode Stability (MIT) }\end{array}$ \\
\hline & $\begin{array}{l}\text { Nickelate Systems: Performance and Limitations } \\
\text { o Studies on LiNi } 1_{1-\mathrm{x}} \mathrm{Mn}_{\mathrm{x}} \mathrm{O}_{2} \text { (SUNY, Stony Brook) } \\
\text { o Preparation Routes for Layered Structures (UT, Austin) } \\
\text { o Layered Mixed Metal Oxides (SUNY, Binghamton) } \\
\text { o MPACVD Carbon Films on Gen } 2 \text { and } 3 \text { Cathodes (LBNL) } \\
\text { o Carbon Redistribution and Capacity/Power Fade in Gen } 2 \text { Cathodes } \\
\text { (LBNL) } \\
\text { o In-situ Diagnostics of Gen } 2 \text { and } 3 \text { Cathodes (BNL) }\end{array}$ \\
\hline New Anode Materials & $\begin{array}{l}\text { o Li-Mg Alloy Anodes (LBNL) } \\
\text { o AlSb SEI Investigation (ANL) } \\
\text { o Intermetallics and Li Coating (ANL) } \\
\text { o Nano-sized Tin Based Anode Materials (SUNY, Binghamton) } \\
\text { o Oxide Based Anodes (SUNY, Binghamton) } \\
\text { o Li Dendrite Growth and Diagnostics (Columbia Univ) }\end{array}$ \\
\hline Novel Electrolytes and Their Characterization & $\begin{array}{l}\text { o Liquid vs. Gel Type Electrolytes and Abuse Tolerance (LBNL) } \\
\text { o Effects of Impurities, Particularly Water, on Interfacial Behavior of } \\
\text { Electrolytes (LBNL) } \\
\text { o Nanostructured Polymer Electrolytes (LBNL) } \\
\text { o Single Ionic Conductors and Ionic Liquids (Clemson Univ) } \\
\text { o Molecular Dynamics of Li }{ }^{+} \text {Transport in Ionic Liquids and Plasticized Ionic } \\
\text { Liquids (Univ Utah) } \\
\text { o Characterization of Ionic Liquids (LBNL) } \\
\text { o Gel Electrolytes (Hydro Quebec) }\end{array}$ \\
\hline Li-Ion Modeling, Diagnostics, and Cell Analysis & $\begin{array}{l}\text { o Interfacial Chemistry at Low Temperature (LBNL) } \\
\text { o Molecular Dynamics Simulations of } \mathrm{Li}^{+} \text {at EC - Graphite Interface (Univ. of } \\
\text { Utah) } \\
\text { o Modeling Electrochemical Performance (Univ Michigan) } \\
\text { o Microscopic Model of Conduction in Oxides (LBNL) } \\
\text { o Cell Optimization Modeling (LBNL) } \\
\text { o Thermodynamic and Transport Property Measurements (LBNL) } \\
\text { o Cell Construction (LBNL) }\end{array}$ \\
\hline
\end{tabular}

Table 7: Overview of the current R\&D tasks in the focused fundamental research activity 


\begin{tabular}{|c|c|}
\hline Task & Highlight \\
\hline New Cathode Materials & 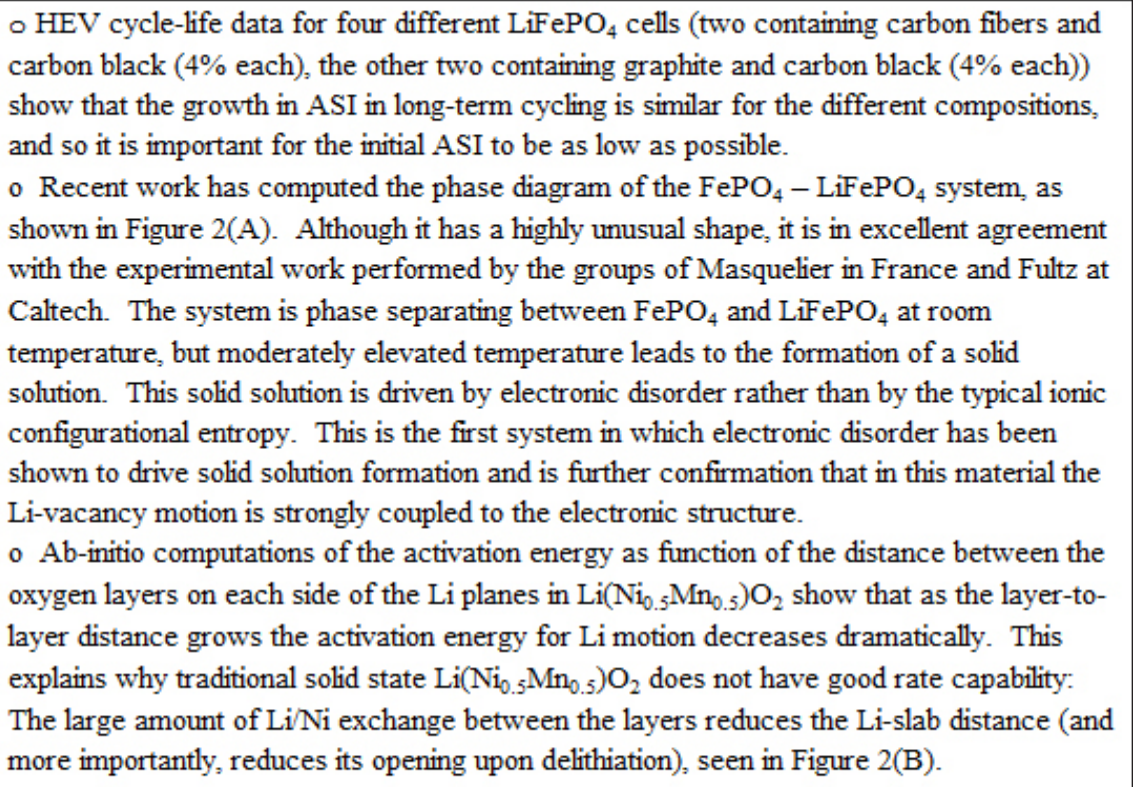 \\
\hline New Anode Materials & $\begin{array}{l}\text { o It was recently demonstrated that amorphous materials cycled much better than the } \\
\text { crystalline tin or tin-cobalt compounds. }\end{array}$ \\
\hline Novel Electrolytes, Characterization & $\begin{array}{l}\text { TGA measurements of gel polymer electrolytes (EC/EMC-LiPF } 6 \text { with cross-linked } \\
\text { polyethers (PEO-type)) and PVDF (phase separating) show that the presence of the } \\
\text { polymer does little, if anything, to suppress the volatility of the liquid electrolyte } \\
\text { components. }\end{array}$ \\
\hline $\begin{array}{l}\text { Li-Ion Modeling, Diagnostics, and } \\
\text { Cell Analysis }\end{array}$ & $\begin{array}{l}\text { - Recently, molecular dynamic simulations of the lithium alkyl monocarbonate (LiMC) } \\
\text { were finalized and contrasted with the previous results for the lithium alkyl dicarbonate SEI } \\
\text { components ( } \mathrm{Li}_{2} \mathrm{EDC} \text { ). Conclusions from this work include that the temperature } \\
\text { dependence of the SEI materials' conductivity is significantly stronger than for liquid } \\
\text { electrolytes, that LiMC has higher conductivity than EDCLi } 2 \text {, and that the resistance of a } \\
\text { thin SEI layer could well exceed resistance of bulk electrolyte. }\end{array}$ \\
\hline
\end{tabular}

Table 8: Recent highlights from the focused fundamental research activity (summarized from [6])

(a)

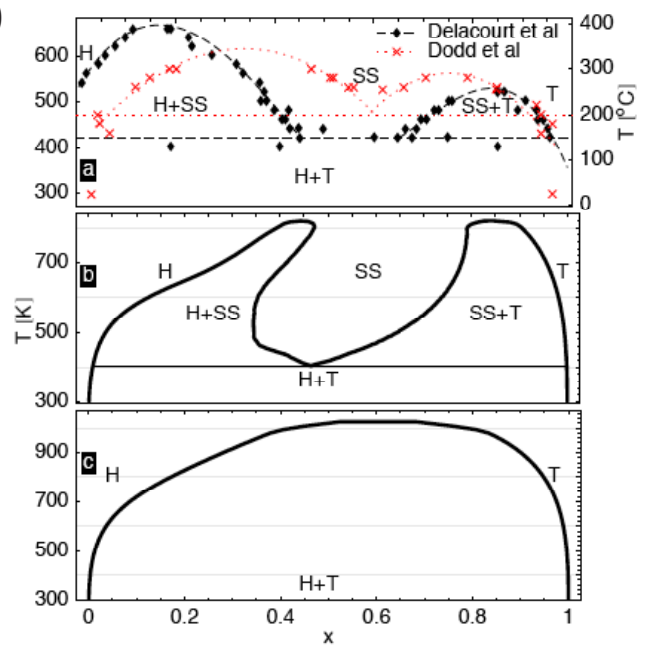

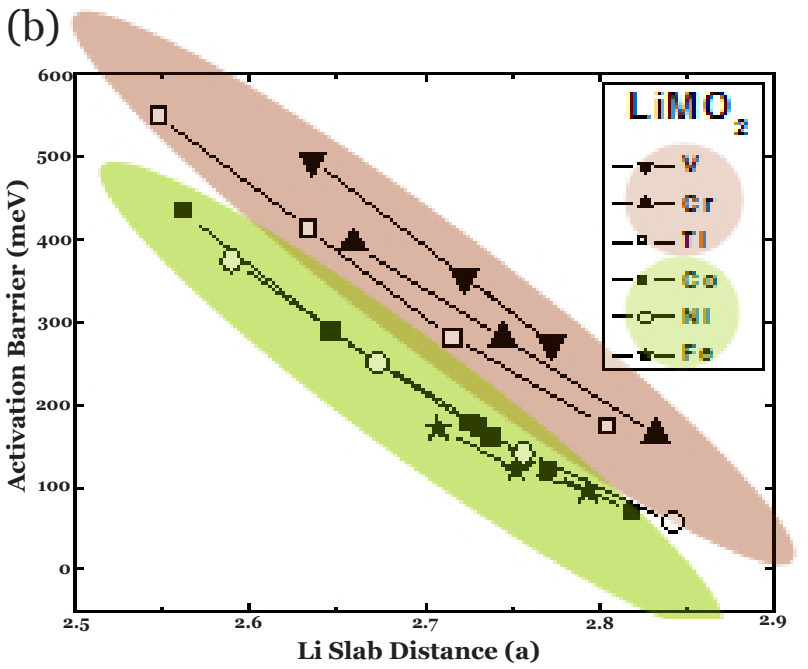

Figure 2:(a) $\mathrm{Li}_{x} \mathrm{FePO}_{4}$ phase diagram, (b) Li migration activation energy vs. interlayer spacing for several "M" atoms 


\section{PLUG-IN HYBRID ELECTRIC VEHICLE BATTERY R\&D}

Current HEVs only use their gasoline engines to charge an on-board battery and they can only travel 1-2 miles in the battery-alone mode, that too at a significantly reduced performance. PHEVs would run either on electricity or on gasoline and can be plugged into the electric grid at night to charge the batteries. They would cover a greater range (in tens of miles) on battery power alone. The Advanced Energy Initiative (AEI) [10], initiated by the current U.S. Administration, provided a $22 \%$ increase in research funding for clean-energy technology at DOE and envisioned innovative ways to fuel U.S. vehicles and power U.S. homes and businesses in the future. AEI incorporates both near-term and long-term approaches. The near-term approaches are primarily regulatory. The long-term approaches involve accelerated efforts to radically improve technologies, including advanced battery technologies for PHEVs. As an initial step in implementing the relevant portions of the AEI, DOE organized a discussion meeting on the PHEV technology in Washington, D.C. in early May 2006. Its objectives were to initiate a dialog among hybrid designers/producers and electric utilities for the purpose of specifying mutually desirable plug-in hybrid and utility attributes and to identify and prioritize areas for research and development. A follow־on meeting was held in June 2007.

Compared to HEVs, lithium-ion batteries for PHEVs (and EVs) are further from commercialization. An improvement in energy density is needed to facilitate such commercialization. For PHEV batteries, the critical barriers include a high cost (since currently, their cost is estimated to exceed $\$ 1,000$ per $\mathrm{kWh}$, and the goal is $\$ 500$ per $\mathrm{kWh}$, or less), inadequate abuse tolerance (an issue similar to the case of the HEV batteries, yet more serious because of the higher energy levels), and other such issues as too large a volume and too much weight, as well as insufficient life. The discharge power may also become a prominent issue, especially at low temperatures. The goal of the PHEV R\&D is to reduce the cost to $\$ 500 / \mathrm{kWh}$ in the short-term (2010) and to further reduce it to $\$ 250 / \mathrm{kWh}$ in the long-term (2015). This cost reduction needs to take place without a degradation in the battery performance.

In collaboration with the USABC, FCVT has developed a set of PHEV battery requirements and test protocols which have been made available at the USABC web-site [11]. In developing those PHEV battery performance requirements, considerable modeling and simulation work was completed at ANL and NREL. State-of-theart battery data were integrated with system models for a variety of vehicle platforms designed to operate in several "all-electric range" modes (covering 10 to 60 miles). DOE also procured, after developing their specifications, state-of-the-art PHEV lithium-ion batteries which are undergoing cycle life testing at ANL/Southern California Edison (SCE). Also, battery hardware-in-the-loop testing is taking place at ANL.

DOE's PHEV battery R\&D activities include R\&D on candidate cathodes for this application, including that on next-generation olivine, layered, and spinel structures, and new high capacity positive materials (with an energy density exceeding $250 \mathrm{mAh} / \mathrm{g}$ ). The anode candidates include novel inter-metallic alloys, nanophase metal oxides, and $\mathrm{Li}$ metal systems. Candidate electrolytes include high voltage electrolytes (4.5 - 5 Volts), composite electrolytes that suppress dendrite formation, and non-flammable electrolytes.

In April 2007, DOE issued, through the USABC, a $\$ 28$ million solicitation for PHEV battery development. The purpose of this solicitation was to fund battery developers to develop, design, build, and test PHEV battery hardware (cells and modules) with the potential to meet the USABC PHEV energy storage performance requirements. This solicitation is expected to result in multiple development awards during FY 2007.

\section{ENERGY STORAGE COLLABORATIVE ACTIVITIES}

The DOE coordination efforts with other government agencies are extensive and comprehensive. Such efforts include membership and participation in the Chemical Working Group of the Interagency Advanced Power Group (IAPG), active participation in program reviews and technical meetings sponsored by other government agencies, and coordinating the participation of representatives from other government agencies in the contract and program reviews of DOE-sponsored efforts. Recent attendees have included representatives from such agencies as the U.S. Army-TACOM, U.S. ArmyCERDEC, NRO, CIA, ONR, NSWC, NASA, and JPL. While no other Federal agency has the same set of performance and cost requirements for energy storage systems as FCVT, other agencies do have similar interests at the level of early R\&D. DOE carefully coordinates R\&D efforts to maximize effectiveness and avoid any duplication of effort. Recent examples of such cooperation include:

- The Navy and DOE jointly funding studies of capacitors and large batteries (built from small, commercially available cells) under abusive conditions.

- DOE awarding contracts for the development of conductive polymer electrolytes that built 
upon work originally funded by the Army and Air Force.

- The Army, Navy, and Air Force awarding multiple contracts to battery suppliers for the development and production of batteries using technology developed with DOE support. (Specific past examples include the Army TACOM/ManTech funding to Saft, Air Force and Navy funding to EEI, Navy funding to T/J Technologies, and multiple contracts to Cobasys/OBC.)

Internationally, the U.S. cooperates with other countries, including Japan, and specifically with the Lithium Battery Energy Storage Research Association. The DOE is a member of the Executive Committee of the International Energy Agency (IEA) Implementing Agreement on Hybrid and Electric Vehicles and participates in various Annexes of the Implementing Agreement. It currently participates in Annex I: "Information Exchange", Annex VII: "Hybrid Vehicles", Annex X: "Electro Chemistry" and Annex XI: "Twowheeled Electric Vehicles". It attends the Executive Committee meetings held in various countries and also provides status updates on other implementing agreements. In addition to monitoring world-wide developmental activities, DOE also keeps abreast of legislative and regulatory mandates that could impact EVs, HEVs, PHEVs, and FCVs in the U.S.

\section{CONCLUSION}

DOE FreedomCAR and Vehicle Technologies R\&D activities in the energy storage area are focused on advanced batteries for transportation applications with a current emphasis on PHEVs. The past successful commercialization of DOE-funded batteries is a testimony to the success achieved by the DOE-USABC cooperative program. Future advances in energy storage technologies will be leveraged with the significant progress achieved in other enabling technologies (such as heat engines, fuel cells, lightweight materials, power electronics, and fuels) to achieve the challenging goals of the FCVT Program. The Program office will continue to reassess longer-term technologies that promise performance, life, and cost benefits over the nickel metal hydride and lithium-ion technologies as candidates for future development and use in hybrid propulsion systems.

\section{REFERENCES}

[1] Office of FreedomCAR and Vehicle Technologies, FreedomCAR and Vehicle Technologies Multi-Year Program Plan, U.S. Department of Energy, June 2005. [2] Howell, D., Duong, T. Barnes, J., Henriksen, G., McLarnon, F., and Kumar, B. J., Current Overview of U.S. Department of Energy Research on Energy Storage For Transportation Systems, the 22nd International Battery, Hybrid, and Fuel Cell Electric Vehicle Symposium and Exhibition, Yokohama, Japan, October 2006.

[3] Howell, D., Duong, T. Barnes, J., Henriksen, G., McLarnon, F., and Kumar, B. J., An Overview of Current Research Projects on Advanced Energy Storage Technologies for Transportation Systems, Funded by the U.S. Department of Energy, the 21st International Battery, Hybrid, and Fuel Cell Electric Vehicle Symposium and Exhibition, Monaco, April 2005.

[4] Duong, T. Q., Barnes., J.A., Battaglia, V., Henriksen, G. H., McLarnon, F., Kumar, B. J., Weinstock, I., U.S. Department of Energy Collaborative R\&D on Electric and Hybrid Electric Vehicle Energy Storage Technologies: Current Status and Future Directions, the 20th International Battery, Hybrid, and Fuel Cell Electric Vehicle Symposium and Exhibition, Long Beach, California, November 2003.

[5] United States Advanced Battery Consortium (USABC) section of the United States Council for Automotive Research (USCAR) web page, http://www. uscar.org/consortia\&teams/consortiahomepages/conusabc.htm.

[6] Office of FreedomCAR and Vehicle Technologies Program, Energy Storage Research and Development, 2006 Annual Progress Report, U.S. Department of Energy, Washington, DC, January 2007, http://www1. eere.energy.gov/vehiclesandfuels/pdfs/program/2006_ energy_storage.pdf.

[7] United States Advanced Batteries Consortium, USABC Electric Vehicle Battery Test Procedure Manual, Rev. 2, U.S. Department of Energy, DOE/ID 10479, January 1996.

[8] U.S. Department of Energy, PNGV Battery Test Procedures Manual, Rev. 2, August 1999, DOE/ID10597.

[9] Berkeley Electrochemical Research Council, Batteries for Advanced Transportation Technologies Program, Lawrence Berkeley National Laboratory, http://berc.lbl.gov/BATT/BATT.html.

[10] Bush, President George W., the 2006 State of the Union Address, January 31, 2006.

[11] United States Council for Automotive Research, RFP and Goals for Advanced Battery Development for Plug-in Electric Vehicles, http://www.uscar.org/guest/ article_view.php?articles_id=97, April 2007.

\section{AUTHORS}

Office of FreedomCAR and Vehicle Technologies, U.S. Department of Energy, 1000 Independence Ave SW, Washington, DC 20585. Phone: 202-586-2210, fax: 202-586-2476, Tien.Duong@ee.doe.gov. Tien Duong is Vehicles Technologies Team Lead at the Department 


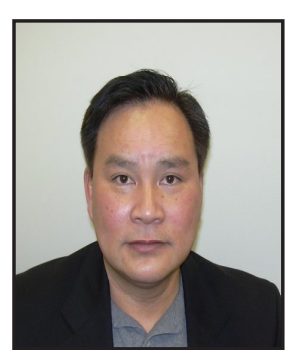

of Energy's FreedomCAR and Vehicle Technologies Program Office. He received his M.S. degree in Civil Environmental Engineering, and his B.S. degree in Electrical Engineering, from Virginia Polytechnic Institute and State University in Blacksburg, Virginia.

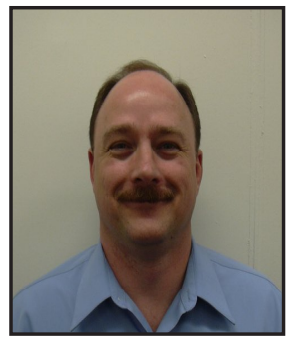

Office of FreedomCAR and Vehicle Technologies, U.S. Department of Energy, 1000 Independence Ave SW, Washington, DC 20585. Phone: 202-586-2210, fax: 202-586-2476, David.Howell@ ee.doe.gov. David Howell is Energy Storage R\&D Manager at the Department of Energy's FreedomCAR and Vehicle Technologies Program Office. He received his B.S. degree in Aerospace Engineering, from the University of Tennessee in Knoxville, Tennessee.

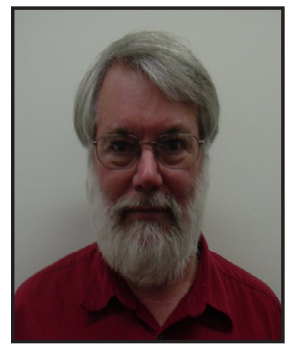

Office of FreedomCAR and Vehicle Technologies, U.S. Department of Energy, 1000 Independence Ave SW, Washington, DC 20585. Phone: 202-586-5657, fax: 202586-2476, James.Barnes@ ee.doe.gov. James A. Barnes is Technology Development Manager at the Department of Energy's FreedomCAR and Vehicle Technologies Program Office. He has worked with advanced batteries at the Navy and DOE for over 20 years. He received his Ph.D. in Inorganic Chemistry from the University of North Carolina at Chapel Hill and his B.S. in Chemistry from Davidson College.

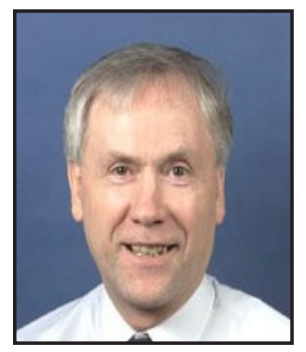

Department Manager, Battery Technology Department, Argonne National Laboratory, 9700 South Cass Ave, Bldg 205, Argonne, IL 60439. Phone: 630252-4591, fax: 630-252-4176, henriksen@cmt.anl.gov. Gary Henriksen is Manager of the Battery Technology Department at Argonne National Laboratory. He leads DOE's Advanced Technology Development Program that involves participation by five DOE laboratories. He received his M.S. degree in Physical and Inorganic Chemistry from Catholic University of America and his B.S. degree in Chemistry and Mathematics from the University of Wisconsin.

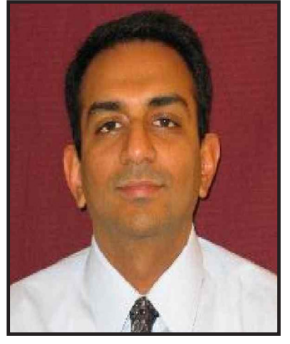

Scientist/Engineer, Lawrence Berkeley National Laboratory, MS 70 R-108B, Berkeley, CA 94720. Phone: 510-495-2679, fax: 510486-4260, vsrinivasan@lbl.gov.

Venkat Srinivasan leads and participates in the Batteries for Advanced Transportation Program at the Lawrence Berkeley National Laboratory. He earlier worked at the Electrochemical Engine Center at Pennsylvania State University. He received his Ph.D. in Chemical Engineering from the University of South Carolina, Columbia and a B.Tech. in Electrochemical Engineering from the Central Electrochemical Research Institute in India. 